\title{
Penerapan Model Pembelajaran Inkuiri terbimbing untuk Meningkatkan Hasil Belajar Kognitif Peserta Didik Kelas XI SMAN 4 bau Bau pada Materi Elastisitas dan Hukum Hooke
}

\author{
Selfi Natalija ${ }^{1 * *}$, Luh Sukariasih $^{2)}$, La Sahara ${ }^{2)}$ \\ ${ }^{1)}$ Alumni Jurusan Pendidikan Fisika FKIP Universitas Halu Oleo \\ ${ }^{2)}$ Dosen Jurusan Pendidikan Fisika FKIP Universitas Halu Oleo \\ Email: selfynataliza@gmail.com
}

\begin{abstract}
This study aims to determine differences in cognitive learning outcomes material elasticity and hooke law students in class XI SMAN 4 Baubau who learn through guided inquiry learning models and conventional learning models. The population of this study was students of class XI of SMAN 4 Baubau in the odd semester of the 2019/2020 academic year totaling 180 students. The sampling technique is simple random sampling so that two classes are obtained, namely the experimental class $\left(X I M I A_{6}\right)$ and the control class $\left(X I M I A_{3}\right)$. Data collection techniques for learning outcomes use objective tests. Data analysis techniques using descriptive statistics and inferential statistics. Based on the results of data analysis and discussion, conclusions are obtained: 1) the initial test picture of learning outcomes of experimental class students using guided inquiry learning models obtained an average value of 38.9, while in the control class using conventional learning obtained an average value of 35.03 and the final test picture of learning outcomes of experimental class students obtained an average value of 74.9, while in the control class an average value of 69.7 was obtained; 2) the average value of the initial test learning outcomes of experimental class students is the same or there is no significant difference with the control class at $\alpha=$ $0.05 ; 3)$ the average value of the final test student learning outcomes of the experimental class there are significant differences from the control class at $\alpha=0.05$; 4) the average value of $\mathrm{N}$-gain learning outcomes of students in the experimental class was significantly better than the control class at $\alpha=0.05$.
\end{abstract}

Keywords: Guided Inquiry Learning Model, Conventional Learning, Student Learning Outcomes.

Abstrak: Penelitian ini bertujuan untuk mengetahui perbedaan hasil belajar kognitif materi elastisitas dan hukum hooke peserta didik kelas XI SMAN 4 Baubau yang belajar melalui model pembelajaran inkuiri terbimbing dan model pembelajaran konvensional. Populasi penelitian ini adalah peserta didik kelas XI SMAN 4 Baubau semester ganjil tahun pelajaran 2019/2020 berjumlah 180 peserta didik. Teknik pengambilan sampel adalah simple random sampling sehingga diperoleh dua kelas yaitu kelas eksperimen (XI MIA ${ }_{6}$ ) dan kelas kontrol (XI MIA $)_{3}$. Teknik pengumpulan data hasil belajar menggunakan tes obyektif. Teknik analisis data menggunakan statistik deskriptif dan statistik inferensial. Berdasarkan hasil analisis data dan pembahasan diperoleh kesimpulan: 1) gambaran tes awal hasil belajar peserta didik kelas eksperimen dengan menggunakan model pembelajaran inkuiri terbimbing diperoleh nilai rata-rata 38,9 sedangkan pada kelas kontrol dengan menggunakan pembelajaran konvensional diperoleh nilai rata-rata 35,03 dan gambaran tes akhir hasil belajar peserta didik kelas eksperimen diperoleh nilai rata-rata 74,9, sedangkan pada kelas kontrol diperoleh nilai rata-rata 69,$7 ; 2$ ) nilai rata-rata tes awal hasil belajar peserta didik kelas eksperimen sama atau tidak terdapat perbedaan yang signifikan dengan kelas kontrol pada $\alpha=0,05$; 3) nilai rata-rata tes akhir hasil belajar peserta didik kelas eksperimen terdapat perbedaan yang signifikan dari pada kelas kontrol pada $\alpha=0,05$; 4) nilai rata-rata $\mathrm{N}$-gain hasil belajar peserta didik kelas eksperimen lebih baik secara signifikan dari kelas kontrol pada $\alpha=0,05$.

Kata Kunci: Model Pembelajaran Inkuiri Terbimbing, Pembelajaran Konvensional, Hasil Belajar Peserta Didik.

\section{PENDAHULUAN}

Proses belajar mengajar juga harus adanya keterlibatan peserta didik yang berperan aktif dalam proses pembelajaran agar peserta didik lebih mudah dan cepat memahami materi yang diajarkan. Kurangnya keterlibatan peserta didik dalam proses pembelajaran yang dikarenakan guru lebih mendominasi sehingga peserta didik cenderung bersifat pasif karena peserta didik hanya mendengarkan, mencatat, mengerjakan tugas yang diberikan oleh guru. Proses pembelajaran yang berpusat pada guru inilah yang dapat membuat peserta didik kurang mengerti dan tidak memahami materi yang diajarkan. Akibatnya peserta didik kurang memahami konsep-konsep yang ada pada materi pembelajaran. Salah satu model pembelajaran pada kurikulum 2013 yang dapat membantu peserta didik aktif dalam proses pembelajaran adalah model 
pembelajaran inkuiri terbimbing. Dalam pembelajaran inkuiri terbimbing para peserta didik bebas dan aktif mengembangkan konsep yang mereka pelajari dengan bimbingan guru selama proses pembelajaran. Peserta didik diberi kesempatan untuk memecahkan masalah yang mereka hadapi secara individu atau berkelompok, di dalam kelas serta menggali informasi untuk menyelesaikan permasalahan fisika. Mereka juga diajarkan berinteraksi sosial dengan kawan sebayanya untuk saling bertukar informasi antar kelompok. Inkuiri merupakan suatu rangkaian kegiatan pembelajaran yang melibatkan secara maksimal seluruh kemampuan siswa untuk mencari dan menyelidiki secara sistematis, kritis, dan logis sehingga mereka dapat menemukan sendiri pengetahuan, sikap, dan skill sebagai wujud adanya perilaku, Hanafiah \& Suhana, (2009) dalam Ardiyansyah, (2018). Pembelajaran inkuiri memiliki beberapa tahapan yakni menetapkan masalah, merumuskan hiposesis, melakukan percobaan/eksperimen, mengolah dan menganalisis data, menguji hipotesis hingga membuat kesimpulan.

Beberapa penelitian sebelumnya menunjukkan sejumlah pengaruh penggunaan model pembelajaran inkuiri terbimbing dalam pembelajaran di kelas. Penelitian Wahyuni, R. dkk, (2016) menyatakan bahwa nilai $\mathrm{N}$-gain kelas model pembelajaran inkuiri terbimbing lebih baik secara signifikan dibandingkan kelas menggunakan model pembelajaran langsung yaitu $64,85 \%$ pada kelas eksperimen dan 43,98\% pada kelas kontrol. Yulian, dkk, (2015) menyatakan bahwa model pembelajaran inkuiri terbimbing dengan metode eksperimen mengalami peningkatan hasil pada aktivitas siswa dan hasil belajarnya. Hasil belajar aspek kognitif peserta didik yang diperoleh peserta didik yaitu 68,97 dan rata-rata nilai aktivitas belajar peserta didik sebesar 73,90 pada kelas kontrol, sedangkan pada kelas eksperimen diperoleh hasil belajar aspek kognitif sebesar 77,32 dan rata-rata nilai aktivitas belajar peserta didik sebesar 83,51.Selanjutnya, penelitian Sipangkar, Yeni (2017) menyatakan bahwa hasil belajar kelas eksperimen yang menerapkan model inkuiri terbimbing lebih tinggi daripada hasil belajar kelas kontrol yang menggunakan pembelajaran konvensional. hasil belajar kelas eksperimen $64 \%$ sedangkan hasil belajar peserta didik pada kelas kontrol $47 \%$. Hal ini, karena pembelajaran inkuiri terbimbing peserta didik dapat membangun sendiri pengetahuan mereka melalui penyelidikan yang mengikuti prosedur ilmiah.

Berdasarkan hasil observasi dan wawancara peneliti dengan guru bidang studi fisika di SMA Negeri 4 Baubau di kelas XI MIA diperoleh informasi bahwa Kegiatan pembelajaran yang di lakukan guru masih menggunakan metode konvensional dalam hal ini, proses pembelajaran masih berpusat pada guru. Guru hanya menjelaskan materi dan rumus, memberikan contoh soal dan memberikan penugasan, sedangkan peserta didik hanya mendengarkan apa yang dijelaskan guru dan mengerjakan soal-soal yang diberikan oleh guru, sehingga guru kurang memperhatikan keseluruhan situasi belajar di dalam kelas. Sehingga, kemampuan peserta didik dalam kerja ilmiah seperti merumuskan pertanyaan, menggunakan alat, mengumpulkan data, atau melakukan percobaan kurang dilatihkan oleh guru sehingga hasil belajarnya kurang optimal. Hal ini terlihat, rata-rata hasil belajar peserta didik pada materi pelajaran fisika yaitu ditunjukkan oleh nilai rata-rata peserta didik pada materi elastisitas dan hukum hooke tahun ajaran 2017/2018 yang tersebar dalam enam kelas yakni rata-rata sebesar 72,28 dari jumlah 172 peserta didik dan pada tahun 2018/2019 yaitu 70,91 dari jumlah 174 peserta didik. Oleh karena itu, memilih materi elastisitas dan hukum Hooke untuk diterapkan dengan model pembelajaran inkuiri terbimbing karena dalam model ini dapat melakukan penyelidikan atau eksperimen sehingga dapat menemukan sendiri konsep-konsep elastisitas dan hukum Hooke. Rendahnya hasil belajar dan kurangnya aktivitas belajar peserta didik menjadi permasalahan yang terjadi di sekolah. Untuk menyikapi permasalahan yang ada tersebut, maka diperlukan suatu model pembelajaran yang berorientasi pada peserta didik sehingga pembelajaran lebih berpusat pada peserta didik (student center) bukan hanya berpusat pada guru (teacher center). Model pembelajaran yang dimaksud adalah modelpembelajaran inkuiri terbimbing. Model ini tentunya diharapkan dapat memberikan perubahan pada hasil belajar fisika menjadi lebih baik dari sebelumnya.

Berdasarkan uraian tersebut, bahwa penerapan model pembelajaran inkuiri terbimbing diharapkan dapat meningkatkanhasil belajar fisika peserta didik, sehingga dipandang perlu dilakukan suatu penelitian dengan judul "Penerapan Model Pembelajaran Inkuiri Terbimbing untuk Meningkatkan Hasil Belajar Kognitif Peserta Didik 
Kelas XI SMAN 4 Baubau pada Materi Elastisitas dan Hukum Hooke".

\section{METODE}

Penelitian ini merupakan jenis penelitian eksperimen. Dengan demikian penelitian ini digunakan dua kelas yaitu kelas eksperimen dengan menggunakan model pembelajaran inkuiri terbimbing dan kelas kontrol dengan menggunakan model pembelajaran konvensional. Penelitian ini dilaksanakan mulai pada tanggal 31 Agustus sampai 12 September pada semester ganjil tahun pelajaran 2019/2020 di SMA Negeri 4 Baubau Provinsi Sulawesi Tenggara.

\section{Desain Penelitian}

Desain penelitian eksperimen yang digunakan adalah Pre-test Post-test Control Group Design (Sugiyono, 2012). Rancangan dalam penelitian ini dapat disajikan sebagai berikut.

Eksperimen : $\begin{array}{llll}\mathrm{R} & \mathrm{O}_{1} & \mathrm{X} & \mathrm{O}_{2}\end{array}$

Kontrol : $\quad \mathrm{R}_{3} \mathrm{O}_{3}-\mathrm{O}_{4}$

Keterangan :

$\mathrm{X}_{1}$ : model pembelajaran inkuiri terbimbing

-----: kelompok peserta didik kelas eksperimen dan kelas kontrol terpisah secara paralel

$\mathrm{O}_{1}$ : skor pre test untuk kelas eksperimen

$\mathrm{O}_{2}$ : skor post test untuk kelaseksperimen

$\mathrm{O}_{3}$ : skor pre test untuk kelas kontrol

$\mathrm{O}_{4}$ : skor post test untuk kelas kontrol

$\mathrm{R}$ : Kelompok eksperimen dan kontrol diambil secara random

\section{Populasi dan Sampel Penelitian}

Populasi dalam penelitian ini adalah seluruh peserta didik kelas XI di SMA Negeri 4 Baubau
Tahun Ajaran 2019/2020 yang secara paralel tersebar 6 kelas yaitu:

Tabel 1. Distribusi Populasi Peserta didik Kelas XI MIA SMAN 4 Baubau Semester Ganjil Tahun Pelajaran 2019/2020.

\begin{tabular}{ccccc}
\hline No & Kelas & $\begin{array}{c}\text { Laki-Laki } \\
\text { (orang) }\end{array}$ & $\begin{array}{c}\text { Perempuan } \\
\text { (orang) }\end{array}$ & Jumlah (orang) \\
\hline 1. & XI MIA $_{1}$ & 13 & 18 & 31 \\
\hline 2. & XI MIA $_{2}$ & 9 & 23 & 31 \\
\hline 3. & XI MIA $_{3}$ & 11 & 18 & 29 \\
\hline 4. & XI MIA $_{4}$ & 11 & 19 & 30 \\
\hline 5. & XI MIA $_{5}$ & 13 & 17 & 30 \\
\hline 6. & XI MIA $_{6}$ & 7 & 22 & 29 \\
\hline & Jumlah & & & $\mathbf{1 8 0}$ \\
\hline
\end{tabular}

Dalam penelitian ini sampel yang diambil yaitu dua kelas secara acak dengan teknik Simple Random Sampling. Sampel diambil dari populasi yang telah diuji homogenitasnya. Adapun populasi yang homogen sebagai berikut: (1) kelas XI MIA dan XI MIA ${ }_{2}$; (2) kelas XI MIA 1 dan XI MIA ${ }_{3}$; (3) kelas X1 MIA 1 dan XI MIA 4 ; (4) kelas XI MIA 1 dan $\mathrm{XI} \mathrm{MIA}_{6}$; (5) kelas XI MIA 2 dan XI MIA ${ }_{3}$; (6) kelas $\mathrm{XI} \mathrm{MIA}_{4}$ dan XI MIA 5 ; (7) kelas XI MIA 4 dan XI MIA $_{6}$; dan (8) kelas XI MIA 5 dan XI MIA 6 . Jika populasi homogen, maka untuk menentukan kelas eksperimen dan kelas kontrol dilakukan dengan cara diundi. Dari hasil proses pengundian diperoleh kelas
XI MIA 6 sebagai kelas eksperimen dan kelas XI $\mathrm{MIA}_{3}$ sebagai kelas kontrol.

\section{Prosedur Penelitian}

Langkah-langkah yang dilakukan dalam penelitian ini antara lain sebagai berikut.

1. Melakukan survei/observasi pada tempat penelitian untuk mengetahui keadaan sekolah, jumlah populasi yang akan dijadikan objek penelitian.

2. Mengambil data nilai hasil ulangan harian sebelum materi elastisitas dan hukum Hooke untuk menguji homogenitasnya. 
3. Menentukan sampel penelitian.

4. Menyusun perangkat pembelajaran berupa silabus, RPP, dan LKPD.

5. Membuat kisi-kisi tes uji coba instrumen.

6. Menyusun instrumen tes uji coba dan kunci jawaban tes berdasarkan kisi-kisi yang telah disusun.

7. Mengujicobakan instrumen tes uji coba pada kelas XI MIA.

8. Menganalisis datahasil instrumen tes uji coba pada kelas uji coba untuk mengetahui taraf kesukaran, daya pembeda soal, validitas soal dan reliabilitas soal.

9. Menentukan soal-soal tes yang akan digunakan dalam tes awal dan tes akhir pada pembelajaran inkuiri terbimbing dan pembelajaran konvensional yang memenuhi syarat berdasarkan data 8 .

10.Melaksanakan tes awal untuk materi pokok elastisitas dan hukum Hooke pada peserta didik kelas pembelajaran inkuiri terbimbing dan pembelajaran konvensional.

11.Melakukan pembelajaran dengan model pembelajaran inkuiri terbimbingdan model pembelajaran konvensional dengan masingmasing 3 (tiga) kali pertemuan.

12.Melakukan tes akhir untuk hasil belajar peserta didik pada pembelajaran inkuiri terbimbing dan pembelajaran konvensional.

13. Menganalisis hasil tes belajar

14.Menyusun laporan hasil penelitian.

\section{HASIL DAN PEMBAHASAN}

Hasil penelitian ini diperoleh dari data pretest, post-test dan $\mathrm{N}$-gain hasil belajar untuk peserta didik kelas eksperimen dan kelas kontrol. Data hasil belajar peserta didik disajikan secara singkat pada Tabel 8 berikut.

Tabel 2. Deskripsi Hasil Tes Awal dan Tes Akhir Hasil Belajar Peserta Didik Kelas Eksperimen dan Kelas Kontrol

\begin{tabular}{|c|c|c|c|c|c|}
\hline \multirow{2}{*}{ Interval Nilai } & \multirow{2}{*}{ Kategori } & \multicolumn{2}{|c|}{ Kelas Eksperimen } & \multicolumn{2}{|c|}{ Kelas Kontrol } \\
\hline & & Tes awal & Tes akhir & Tes awal & Tes akhir \\
\hline$<40,00$ & Amat kurang & 16 & 0 & 17 & 0 \\
\hline $40,00-54,99$ & Kurang & 9 & 0 & 11 & 0 \\
\hline $55,00-64,99$ & Cukup & 3 & 2 & 1 & 10 \\
\hline $65,00-79,99$ & Baik & 1 & 17 & 0 & 15 \\
\hline $80,00-94,99$ & Amat baik & 0 & 10 & 0 & 4 \\
\hline$\geq 95,00$ & Istimewa & 0 & 0 & 0 & 0 \\
\hline \multicolumn{2}{|c|}{ Rata-Rata } & 38,9 & 74,9 & 35,03 & 69,7 \\
\hline \multicolumn{2}{|c|}{ Standar Deviasi (SD) } & 12,5 & 5,54 & 9,7 & 6,72 \\
\hline \multicolumn{2}{|c|}{ Maksimum } & 68 & 88 & 64 & 80 \\
\hline \multicolumn{2}{|c|}{ Minimum } & 20 & 64 & 20 & 60 \\
\hline
\end{tabular}

Berdasarkan tabel 2 terlihat bahwa hasil belajar peserta didik pada pre test (tes awal) dan post test (tes akhir) kelas eksperimen dan kelas kontrol berbeda. Dimana, pada kelas eksperimen diperoleh nilai rata-rata pre test (tes awal) hasil belajar peserta didik lebih tinggi dari pada nilai rata-rata kelas kontrol. Begitupun juga pada nilai rata-rata post test (tes akhir) hasil belajar peserta didik kelas eksperimen lebih tinggi dibandingkan dengan nilai rata-rata hasil belajar peserta didik pada kelas kontrol. Akan tetapi, kedua kelas tersebut baik kelas eksperimen maupun kelas kontrol pada nilai ratarata post test (tes akhir) hasil belajar peserta didik mengalami peningkatan. Selanjutnya, pengkategorian $\mathrm{N}$-gain hasil belajar peserta didik pada kelas eksperimen dan kelas kontrol setelah pembelajaran dapat dilihat pada Tabel 3 berikut. 
Tabel 3. Pengkategorian $\mathrm{N}$-gain Hasil Belajar Peserta Didik Kelas Eksperimen dan Kelas Kontrol

\begin{tabular}{|c|c|c|c|c|c|}
\hline \multirow{3}{*}{ Interval Nilai } & \multirow{3}{*}{ Kategori } & \multicolumn{4}{|c|}{ N-gain } \\
\hline & & \multicolumn{2}{|c|}{ Kelas Eksperimen } & \multicolumn{2}{|c|}{ Kelas Kontrol } \\
\hline & & $\mathrm{f}$ & $\%$ & $\mathrm{f}$ & $\%$ \\
\hline $0 \leq \mathrm{g}<0,3$ & Rendah & 0 & 0 & 2 & 6,8 \\
\hline $0,3 \leq \mathrm{g} \leq 0,7$ & Sedang & 25 & 86,2 & 24 & 82,7 \\
\hline $0,7<\mathrm{g} \leq 1$ & Tinggi & 4 & 13,8 & 3 & 10,3 \\
\hline \multicolumn{2}{|c|}{ Rata-Rata } & \multicolumn{2}{|c|}{0,60} & \multicolumn{2}{|r|}{0,52} \\
\hline \multicolumn{2}{|c|}{ Standar Deviasi (SD) } & \multicolumn{2}{|c|}{0,09} & \multicolumn{2}{|r|}{0,13} \\
\hline \multicolumn{2}{|c|}{ Maksimum } & \multicolumn{2}{|c|}{0,75} & \multicolumn{2}{|r|}{0,74} \\
\hline \multicolumn{2}{|c|}{ Minimum } & \multicolumn{2}{|c|}{0,36} & \multicolumn{2}{|r|}{0,22} \\
\hline
\end{tabular}

\begin{tabular}{|r|r|r|r|r|r|}
\hline $\left.\begin{array}{r}100 \\
80 \\
60 \\
40 \\
20\end{array}\right]$ \\
0
\end{tabular}

Gambar 1. Grafik Peningkatan Data Hasil Belajar Peserta Didik

Berdasarkan tabel 9. bahwa secara umum dapat dilihat nilai rata-rata $\mathrm{N}$-gain pada kelas eksperimen terdapat pada kategori sedang $(86,2 \%)$ dan tinggi $(13,8 \%)$ sedangkan pada kelas kontrol nilai rata-rata $N$-gain terdapat pada kategori sedang $(82,7 \%)$, tinggi $(10,3 \%)$ dan rendah $(6,8 \%)$. Hasil $N$-gain kelas eksperimen lebih tinggi dibandingkan dengan kelas kontrol.

\section{Hasil Analisis Inferensial}

a. Uji Normalitas Data

Uji normalitas data dilakukan dengan menggunakan uji kolmogorov smirnov dengan taraf signifikan yang digunakan $\alpha=0,05$. Secara singkat dirangkum dalam Tabel 4 berikut.

Tabel 4. Hasil Uji Normalitas Data Hasil Belajar Fisika Peserta Didik pada Kelas Eksperimen dan Kelas Kontrol

\begin{tabular}{ccccccc}
\hline \multirow{2}{*}{ Variabel } & \multirow{2}{*}{ Kelas } & \multicolumn{6}{c}{ Signifikansi } & Ket \\
\cline { 2 - 5 } & Eksperimen & 29 & 0,591 & 0,400 & \multirow{2}{*}{0,05} & Normal \\
\hline $\begin{array}{l}\text { Hasil Belajar } \\
\text { Peserta Didik }\end{array}$ & Kontrol & 29 & 0,681 & 0,500 & & Normal \\
\cline { 2 - 5 }
\end{tabular}

Berdasarkan hasil uji normalitas data yang diperoleh pada tabel diatas dapat dilihat bahwa pada kelas eksperimen dan kelas kontrol hasil tes awal dan tes akhir terdistribusi normal Karena Asymp siglebih besar dari alpha (Asymp sig $>\alpha$ ) dengan taraf signifikan $(\alpha=0,05) 95 \%$. a. Uji Homogenitas Varians Data

Pengujian homogenitas data dilakukan dengan menggunakan uji lavene dengan taraf signifikan $\alpha=$ 0,05 . Hasil uji homogenitas data hasil belajar peserta didik pada kelas eksperimen dan kelas kontrol secara singkat dapat dilihat pada Tabel 5 berikut. 
Tabel 5. Hasil Pengujian Homogenitas Varians Data Hasil Belajar Peserta Didik

\begin{tabular}{|c|c|c|c|}
\hline \multirow{2}{*}{ Aspek yang Diuji } & \multicolumn{2}{|c|}{ Signifikansi } & \multirow{2}{*}{ Ket } \\
\hline & Asymp sig & $\mathbf{A}$ & \\
\hline Tes awal & 0,111 & \multirow{3}{*}{0,05} & Homogen \\
\hline Tes akhir & 0,157 & & Homogen \\
\hline$N$-Gain & 0,068 & & Homogen \\
\hline
\end{tabular}

Dari tabel 5. menunjukkan bahwa hasil uji homogenitas data hasil belajar peserta didik pada tes awal, tes akhir dan $N$-gain adalah homogen karena

Asymp sig lebih besar dari alpha (Asymp sig $>\alpha$ ) pada taraf signifikan $(\alpha=0,05)$.

b. Hasil Pengujian Hipotesis Penelitian

Tabel 6. Hasil Pengujian Hipotesis Nilai Tes Awal, Tes Akhir dan N-gain Hasil Belajar Peserta Didik pada Kelas Eksperimen dan Kelas Kontrol

\begin{tabular}{|c|c|c|c|c|c|c|}
\hline \multirow{2}{*}{ Variabel } & \multirow{2}{*}{ Aspek yang Diuji } & \multicolumn{3}{|c|}{ Independent Samples Test } & \multirow{2}{*}{$\alpha$} & \multirow{2}{*}{ Ket } \\
\hline & & $\mathbf{t}_{\text {hitung }}$ & $\mathbf{t}_{\text {tabel }}$ & Asymp.Sig & & \\
\hline \multirow{3}{*}{$\begin{array}{l}\text { Hasil Belajar } \\
\text { Peserta Didik }\end{array}$} & Hipotesis I & 1,310 & \multirow{3}{*}{$\begin{array}{c}2, \\
0032\end{array}$} & 0,196 & \multirow{3}{*}{0,05} & $\mathrm{H}_{0}$ diterima \\
\hline & Hipotesis II & 3,240 & & 0,02 & & $\mathrm{H}_{0}$ ditolak \\
\hline & Hipotesis III & 2,033 & & 0,047 & & $\mathrm{H}_{0}$ ditolak \\
\hline
\end{tabular}

Berdasarkan hasil uji hipotesis I, terlihat bahwa Asymp sig lebih besar dari alpha (Asymp sig $>\alpha=$ 0,05) maka dapat disimpulkan bahwa $\mathrm{H}_{0}$ diterima dan $\mathrm{H}_{1}$ ditolak artinya tidak ada perbedaan yang signifikan antara nilai rata-rata hasil tes awal peserta didik pada kelas eksperimen dengan nilai rata-rata hasil tes awal peserta didik kelas kontrol. Selanjutnya, hasil uji hipotesis II, menunjukkan bahwa Asymp sig lebih kecil dari alpha (Asymp sig< $\alpha=0,05)$ sehingga $\mathrm{H}_{0}$ ditolak dan $\mathrm{H}_{1}$ diterima artinya nilai rata-rata hasil tes akhir peserta didik pada kelas eksperimen lebih baik secara signifikan dari pada nilai rata-rata hasil tes akhir peserta didik pada kelas kontrol. Pada hasil uji hipotesis III, terlihat hasil Asymp sig lebih kecil dari alpha (Asymp sig $<\alpha=0,05$ ) sehingga disimpulkan bahwa $\mathrm{H}_{0}$ ditolak dan $\mathrm{H}_{1}$ diterima artinya Nilai rata-rata $N$ gain hasil belajar peserta didik pada kelas eksperimen lebih baik secara signifikan dari pada nilai rata-rata $N$-gain hasil belajar peserta didik pada kelas kontrol.

Berdasarkan penelitian ini, hasil belajar yang diukur adalah kemampuan kognitif peserta didik pada materi pokok elastisitas dan hukum Hooke. Hal ini dilakukan dengan cara memberikan dua perlakuan yang berbeda, yaitu pada kelas eksperimen dengan menggunakan model pembelajaran inkuiri terbimbing dan kelas kontrol dengan menggunakan model pembelajaran konvensional melalui hasil belajar yang diperoleh dari pre test dan post test. Berdasarkan hasil analisis deskriptif menunjukan bahwa sebelum dilakukan pembelajaran baik model pembelajaran inkuiri terbimbing maupun pembelajaran konvensional tingkat kemampuan peserta didik relatif sama karena peserta didik menjawab soal-soal materinya sama yang belum didapatkan sebelumnya atau materi yang diujikan belum diajarkan pada peserta didik, sehingga peserta didik menjawab pertanyaan sesuai dengan pengalamannya dalam kehidupan seharihari. Hal ini terbukti dengan diperolehnya rata-rata hasil tes awal kelas eksperimen sebesar 38,9 dengan standar deviasi 12,5 dan kelas kontrol sebesar 35,03 dengan standar deviasi 9,7. Berdasarkan nilai ratarata tersebut, dianalisis dengan menggunakan uji Independent samples $t$ test pada SPSS 16.0 dinyatakan bahwa tidak ada perbedaan yang signifikan antara nilai rata-rata tes awal peserta didik kelas eksperimen dengan nilai rata-rata tes awalpeserta didik kelas kontrol pada materi pokok elastisitas dan hukum hooke pada taraf signifikan $\alpha$ $=0,05$.

Setelah diterapkan model pembelajaran inkuiri terbimbing pada kelas eksperimen terlihat adanya peningkatan pembelajaran yang lebih baik. Hal ini terbukti dengan diperolehnya nilai rata-rata peserta didik pada kelas eksperimen berdasarkan tes akhir sebesar 74,9 dengan standar deviasi 5,54 dan nilai rata-rata peserta didik pada kelas kontrol dengan rata-rata sebesar 69,7 dengan standar deviasi 6,72. Berdasarkan nilai rata-rata tersebut, di analisis dengan menggunakan uji Independent samples $t$ test pada SPSS 16.0 dinyatakan bahwa Nilai rata-rata hasil tes akhir peserta didik pada kelas eksperimen lebih baik secara signifikan dari pada nilai rata-rata hasil tes akhir peserta didik pada kelas kontrol 
dengan materi pokok elastisitas dan hukum hooke. Perbedaan hasil belajar peserta didik pada tes akhir melalui pembelajaran inkuiri terbimbing dan pembelajaran konvensional. Hal ini disebabkan karena kelas eksperimen yang menggunakan pembelajaran inkuiri terbimbing, peserta didik dapat membangun sendiri pengetahuannya melalui percobaan yang dilakukan dan sebagian peserta didik juga tidak mempersiapkan diri pada saat proses pembelajaran berlangsung dan saat dilaksanakannya tes akhir. Akan tetapi, meskipun ketercapaian hasil belajar nilai tes akhir peserta didik berbeda baik menggunakan model pembelajaran inkuiri terbimbing maupun pembelajaran konvensional sama-sama dapat meningkatkan hasil belajar peserta didik. Penelitian ini didukung oleh penelitian Yeni Sipangkar dkk (2017) menunjukkan bahwa hasil belajar kelas eksperimen yang menerapkan model inkuiri terbimbing lebih tinggi daripada hasil belajar kelas kontrol yang menggunakan pembelajaran konvensional.

Berdasarkan hasil pengujian secara inferensial, peningkatan hasil belajar juga dapat dilihat pada peningkatan nilai $(N$-gain) rata-rata hasil belajar peserta didik. Untuk kelas eksperimen, nilai rata-rata $N$-gain peserta didik sebesar 0,60 sedangkan untuk kelas kontrol nilai $\mathrm{N}$-gain peserta didik sebesar 0,52. Berdasarkan nilai rata-rata tersebut, dianalisis dengan menggunakan uji Independent samples $t$ test pada SPSS 16.0 dinyatakan bahwa nilai rata-rata $N$ gain hasil belajar peserta didik pada kelas eksperimen lebih baik secara signifikan dari pada nilai rata-rata $N$-gain hasil belajar peserta didik kelas kontrol. Hal ini menunjukkan bahwa penerapan model pembelajaran pada kelas eksperimen dengan menggunakan model pembelajaran inkuiri terbimbing lebih mudah diterima dari pada kelas kontrol dengan pembelajaran konvensional. Hal ini dikarenakan kelas yang menerapkan model pembelajaran inkuiri terbimbing dimana peserta didik belajar secara aktif dalam proses pembelajaran, seperti dapat merumuskan masalah, merumuskan hipotesis, merancang percobaan, melakukan percobaan, mengumpulkan dan menganalisis data serta dapat menarik kesimpulan. Hasil belajar peserta didik dengan model pembelajaran inkuiri terbimbing meningkat karena dengan menggunakan model pembelajaran inkuiri terbimbing peserta didik terlibat langsung sehingga termotivasi, peserta didik diberi kesempatan untuk berpartisipasi dalam pembelajaran dan guru membimbing peserta didik, pada proses pembelajaran dikelas peserta didik yang belajar dengan model pembelajaran inkuri terbimbing lebih bebas dalam menemukan konsep sendiri, dan pada kegiatan praktikum peserta didik dapat mengembangkan konsep yang dibuat dengan pengetahuan tim dari kelompok pratikum (Vlassi dan Karaliota, 2013). Hal ini juga sejalan dengan hasil penelitian Wahyuni, dkk (2016), model pembelajaran inkuiri terbimbing dengan metode eksperimen yang diberikan pada kelas ekperimen membuat peserta didik lebih aktif dalam belajar dan meningkatkan hasil belajar fisika peserta didik. Penggunaan metode eksperimen pada model pembelajaran inkuiri ini sangat mendukung peserta didik dalam menemukan konsep-konsep pada materi elastisitas dan hukum Hooke.

Penggunaan model pembelajaran inkuiri terbimbing dapat meningkatkan hasil belajar peserta didik dibandingkan dengan pembelajaran konvensional, tetapi selama proses pembelajaran banyak kendala yang dihadapi yaitu kurangnya penguasaan kelas dan manajemen waktu yang belum tepat dalam proses pembelajaran karena peserta didik harus melakukan percobaan dengan teliti dan tidak terburu-buru untuk memperoleh hasil yang benar-benar maksimal, serta sebagian peserta didik masih ada yang bingung dan kurang serius dalam belajar menggunakan model pembelajaran inkuiri terbimbing karena model inkuiri terbimbing belum pernah diterapkan oleh guru fisika di sekolah tersebut. Dan metode ini memerlukan ketelitian dalam proses belajarnya karena kurangnya ketelitian dapat memberikan hasil yang kurang maksimal. Setelah dilakukan analisis, menurut teori pembelajaran inkuiri, model inkuiri berhasil jika diterapkan kepada peserta didik yang kurang memiliki kemauan dan kemampuan berpikir. Ngalimun (2014) menyatakan bahwa model pembelajaran inkuiri memerlukan jumlah pelajaran kelas yang banyak dan waktu di luar kelas dibandingkan dengan model pembelajaran lainnya serta memerlukan proses mental yang berbeda seperti perangkat analitik dan kognitif.

\section{KESIMPULAN DAN SARAN}

Kesimpulan pada penelitian ini adalah penerapan model pembelajaran inkuiri terbimbing dapat meningkatkan hasil belajar kognitif peserta didik kelas XI SMAN 4 Baubau pada materi elastisitas dan hukum Hooke. Adapun saran yaitu peneliti harus mengelola waktu dengan baik seperti waktu untuk melakukan percobaan, diskusi, dan sebagainya. Selain itu, peneliti harus bersikap tegas 
pada peserta didik yang bermain-main atau melakukan hal-hal yang tidak ada hubungannya dengan kegiatan pembelajaran. Peneliti juga dapat mengembangkan dengan menambah variabel lain seperti motivasi dan minat peserta didik.

\section{DAFTAR PUSTAKA}

Anonim. 2009. Kurikulum dan Pembelajaran. Prenada Media Group. Jakarta.

Anonim. 2006. Strategi Pembelajaran Berorientasi Standar Pendidikan. Kencana. Jakarta.

Anonim. 2010. Dasar-Dasar Evaluasi Pendidikan Edisi Revisi. PT. Bumi Aksara. Jakarta.

Arikunto, S. 2009. Prosedur Penelitian Suatu Pendekatan Praktik Edisi Revisi. Rineka Cipta. Jakarta.

Ambarsari, Wiwin. 2013. Penerapan Pembelajaran Inkuiri Terbimbing Terhadap Keterampilan Proses Sains Dasar pada Pelajaran Biologi Siswa Kelas VIII SMP Negeri 7 Surakarta. Jurnal Surakarta. FKIP-UNS.

Aqib, Zainal.2013. Model-Model, Media, dan Strategi Pembelajaran Kontekstual (Inovatif). Yrama Widya. Bandung.

Fatmawati. 2013. Keefektifan Model Pembelajaran Inkuiri dan Model Pembelajaran Langsung Terhadap Hasil Belajar Peserta Didik pada Sub Materi Pokok Fluida Statis Kelas XI IPA SMAN 1 Lawa. Universitas Halu Oleo. Kendari.

Hamiyah, N. Dan M. Jauhar. 2014. Strategi Belajar Mengajar di Kelas. Prestasi Pustaka. Jakarta.

Hamalik, Oemar 2007. Manajemen Pengembangan Kurikulum. PT. Remaja Rosdakarya. Bandung.

Hartono, Rudi. 2013. Ragam Model Mengajar yang Mudah Ditemukan Murid. DIVA Press. Jogjakarta.

Hake, H.R. 1998. Interactive-engagement versus traditional methods: A six-thousandstudent survey of mechanics test data for introductory physics courses. American Journal of physics, 66 (1), pp. 64-74.

Kemendikbud. 2014. Materi Pelatihan Implementasi Kurikulum. Kementrian Pendidikan dan Kebudayaan. Jakarta.

Justitia, V.S., dan Supardi, Z.A.I. 2015. Penerapan Model Pembelajaran Inkuiri pada Materi
Elastisitas untuk Meningkatkan Hasil Belajar Siswa Kelas X SMA Negeri 1 Kedamean Gresik. Jurnal Inovasi Pendidikan Fisika (JPIF), Vol.04 NO. 03, September 2015, Hal 71-76..

Mulyasa, E, 2005. Menjadi Guru Profesional. Bandung. Remaja Rosdakarya.

Musfiqon dan Nurdyansyah. 2015. Pendekatan Pembelajaran Saintifik. Nizamia Learning Center. Sidoarjo.

Ngalimun. (2016). Strategi dan Model Pembelajaran. Penerbit Aswaja Pesindo, Yogyakarta.

Putra, S.R. 2013. Desain Belajar Mengajar Kreatif Berbasis sains. Bumi Aksara. Yogyakarta.

Ratnasari, J dan Wasis. 2016. Penerapan Model Pembelajaran Inkuiri Terbimbing Berbasis Kegiatan Laboratorium Untuk Meningkatkan Hasil Belajar Siswa Pada Materi Elastisitas Kelas X Sma Negeri 2 Sidoarjo. Jurnal Inovasi Pendidikan Fisika (JIPF) Vol. 05 No. 02, Mei 2016, 1-5 ISSN: 2302-4496.

Rengganis, A.P, dkk. 2015. Penerapan Model Pembelajaran Problem Based Learning Berbasis Inkuiri untuk Meningkatkan Penguasaan Konsep dan Keterampilan Proses Sains Siswa SMP. Universitas Negeri Semarang.

Sanjaya, W. 2008. Strategi Pembelajaran, Berorientasi Standar Proses Pendidikan. Jakarta: Kencana Prenada Media Group.

Sipangkar, Y, Rita Juliani dan Andil Siregar. 2017. Pengaruh Model Pembelajaran Inkuiri Terbimbing Terhadap Hasil Belajar Dan Aktivitas Siswa. Jurnal Pendidikan Fisika p-ISSN2252-732X, e-ISSN 2301-7651.

Sudjana. 2002. Metoda Statistika. Edisi: 6. Tarsito. Bandung.

Sugiyono. 2012. Metode Penelitian Pendidikan Pendekatan Kuantitatif, Kualitatif dan $R$ $\& D$. Alfabeta. Bandung.

Sumartono dan Normalina. 2015. Motivasi dan Hasil Belajar Peserta Didik dalam Pembelajaran Matematika dengan Menggunakan Model Pembelajaran Kooperatif Tipe Scramble di SM. EDUMAT Jurnal Pendidikan Matematika, No.3, no.1. 
Usman, U. \& Lilies S. 2001. Upaya Optimalisasi Kegiatan Belajar Mengajar. PT. Remaja Rosdakarya. Bandung.

Vlassi, M. and Karaliota, A. (2013). The comparison between guided inquiry and traditional teaching method. A case study for the teaching of the structure of matter to $8^{\text {th }}$ grade Greek students. JournalProcediaSocial and Behavioral Sciences, 93 (1) $494-497$.

Wahyuni, Roni, H, dan Taufik M. 2016. Pengaruh Model Pembelajaran Inkuiri Terbimbing dengan Metode Eksperimen Terhadap Hasil Belajar Fisika Siswa Kelas XI IPA SMAN 2 Mataram Tahun Pelajaran
2016/2017. Jurnal pendidikan fisika dan teknologi. Vol II No. 4. ISSN 240769021. 2 (4) 164-169.

Yani, M dan Mamat Ruhimat. 2018. Teori dan Implementasi Pembelajaran Saintifik Kurikulum 2013. Refika Aditama. Bandung.

Yulian, dkk. 2015. Pengaruh Model Pembelajaran Inkuiri Terbimbing (Guided Inquiry) dengan Menggunakan Metode Eksperimen Terhadap Aktivitas dan Hasil Belajar IPA-Biologi Siswa Kelas VIII SMP Negeri 2 Maesan Bondowoso. Vol.4,No.2, hal 163-172. Universitas Jember. 